\title{
Метрополизация «региональных столиц» Центрально- Черноземного района в трансформации размещения населения
}

\author{
Н. В. Чугунова ${ }^{\bowtie}$, Т. А. Полякова, Д. Н. Морковская \\ Белгородский государственный национальный исследовательский университет, \\ Российская Федерация \\ (308015, г. Белгород, ул. Победы, 85$)$
}

\begin{abstract}
Аннотация: Цель: определить роль метрополизации «региональных столиц» Центрально-Черноземного района в трансформации и тенденциях развития расселения населения. Информационной базой служили материалы Федеральной службы государственной статистики (Росстат) и территориальных органов федеральной службы государственной статистики Белгородской, Воронежской, Курской, Липецкой, Тамбовской областей. Meтоды. Решение основных задач работы достигнуто применением методов пространственно-временного и системного анализов, статистических, моделирования, геоинформационного картографирования (ArcGIS), позволившего наглядно представить временной срез процессов и явлений, отобразить притягательную силу областных метрополий в размещении населения. Результаты и обсуждение. Выявлены закономерные изменения в развитии расселения, вызванные процессами урбанизации, метрополизации областей Центрально-Черноземного района. Установлены особенности формирования региональных метрополисов; определены масштабы и тенденции изменений размещения населения на различных территориальных уровнях. Проведена апробация модельного исследования размещения населения, осуществлено картографирование потенциала поля расселения Белгородской области. Выводы. Использование в исследовании принципа рангразмера позволят институтам управления разного иерархического уровня увидеть и решить острые проблемы расселения.
\end{abstract}

Ключевые слова: расселение, метрополисы, метрополизация, потенциал поля расселения, Центрально-Черноземный, Белгородская.

Источник финансирования: Статья подготовлена в рамках научного Проекта РФФИ № 20-05-00074.

Для цитирования: Чугунова Н.В., Полякова Т. А., Морковская Д.Н. Метрополизация «региональных столиц» Центрально-Черноземного района в трансформации размещения населения // Вестник Воронежского государственного университета. Серия География. Геоэкология, 2020, № 4, c. 3-13. DOI: $\underline{\text { https://doi.org/10.17308/geo.2020.4/3060 }}$

\section{ВВЕДЕНИЕ}

Развитие процессов урбанизации, последующее формирование и развитие региональных метрополисов вызывает в системах расселения радикальные изменения: поляризацию расселения в градиенте «центр-периферия», рост социальноэкономической и демографической асимметрии, возникновение определенных вызовов развитию современного общества. Фактором роста любого крупного города, особенно регионального метрополиса, является «агломерационный эффект», эко-

(c) Чугунова Н.В., Полякова Т. А., Морковская Д.Н., 2020

\ Чугунова Надежда Васильевна, e-mail: chugunova@bsu.edu.ru 
фраструктурные преобразования, проникновение процессов глобализации привели к концентрации населения (и бизнеса) в большие города, «региональные столицы» (административные центры областей) и их пригороды, социально-демографическому обезлюдению периферийных районов.

Для оптимизации процессов размещения населения необходимо выявление изменений масштабов численности городского и сельского населения, определение результатов и вариантов дальнейшего развития расселения. Необходимость исследования роли расселения в пространственной организации общества осознана давно, о чем свидетельствуют многочисленные работы в России социальных географов, социологов, экономистов. Вопросам трансформации системы городского расселения посвящался и российско-французский симпозиум, где подчеркивалось сближение траекторий эволюции «региональных столиц» в Западной и Восточной Европе [3]. Растущие экономические и социальные контрасты, поляризация регионального экономического развития, углубление пространственных диспропорций становятся актуальной проблемой исследований $[7,8,20]$.

В Москве с 2012 года регулярно издается журнал Urban Agenda, раскрывающий проблемы урбанистики, в одном из номеров которого глава мировой консалтинговой компании BOSTON CONSULTING CROUP в 2019 году отметил, что неравенство имеет пространственное измерение и приоритетами развития крупных городов должны быть принципы устойчивости в экономическом и социальном планах [2].

Вопросам метрополизации посвящены статьи А. Г. Дружинина [5], рассматривающего метрополизацию как доминантную тенденцию территориальной организации общества, ее активизацию в современной России, одновременно вытягивающей ресурсы периферии [6], углубляющей социально-территориальную стратификацию и сегрегацию в регионе. Нетривиально к понятию и определению метрополии подошел Н. В. Гонтарь [4], считающий, что метрополизация представляет собой процесс формирования системы власти над геопространством, для которой важны вертикальные отношения (центр - периферия, корпорация филиал).

Д. Фридман [23] считал, что в переходных экономиках инвестиции и последующий экономический рост осуществляются точечно и это приводит к территориальному разделению «центр - периферия». Центром становятся городские агломера- ции, в которых концентрируются ресурсы, а периферией - все остальные территории. Экономики агломерации и периферии не подвержены конвергенции - центр развивается, а периферия, лишенная доступа к ресурсам, деградирует.

Французские исследователи [12] убеждены, что в формировании метрополисов лежит ключ к модернизации. Последние исследования Р. Флориды [19] показали, что возникает неравенство между городами: столицы или центры технологических индустрий процветают, а бывшие промышленные города не развиваются и погибают.

Развитие в Центрально-Черноземном районе региональных метрополисов в качестве полюсов роста и концентрации населения [22] предопределяют интенсификацию поляризации расселения в центр-периферийной системе региона, увеличение числа пустеющих сел и постселитебных территорий. А.Э. Крупко [10], занимаясь изучением растущей неоднородности социально-экономического развития территорий ЦЧР, приходит к выводу о снижении устойчивости муниципальных образований, их конкурентоспособности. Исследуя проблемы и основные направления устойчивого развития Центрально-Черноземного района [11], авторы работы устанавливают необходимость достижения сбалансированного состояния между природной средой, социальной и экономическими сферами.

Наши исследования свидетельствуют не только о концентрации населения и экономики в больших городах, но и росте сегрегации населения в градиенте «центр - периферия» [21], нарастающих внутрирегиональных диспропорциях уровней социально-экономического развития муниципальных образований, слабой урбанизации периферии, ее депопуляции.

Объектом нашего исследования является система населения и расселения Центрально-Черноземного района, предметом исследования - процессы урбанизации в районе.

Цель работь - определение роли метрополизации «региональных столиц» Центрально-Черноземного региона в трансформации и тенденциях развития расселения населения.

Основные задачи работы - выявление причин и главных результатов радикальных изменений в системе расселения; определение особенностей процессов формирования областных метрополисов; установление территориальных различий и тенденций перераспределения населения на основе модели потенциала поля расселения Белгородс- 
кой области с использованием инструментов Geostatistical Analyst программы ArcGIS.

\section{МЕТОДОЛОГИЯ И МЕТОДЫ ИССЛЕДОВАНИЯ}

Методология исследования

Под региональной метрополией (метрополисом) понимается главный город конкретной территории, центр политической, экономической жизни с повышенной концентрацией городского населения - верхний уровень в иерархии региональной системы расселения. Ареал метрополии - это компактное территориальное размещение ядра метрополии, коттеджных поселков вне ядра, городов-спутников, сельских поселений, объединенных интенсивными производственными, инфраструктурными, социальными связями. Ареал метрополии идентичен городской агломерации.

Метрополизация - процесс развития метрополии, доминирования столичного центра в социально-экономическом, политическом и пространственном аспектах, результат развития урбанизации.

Под расселением в данной статье будем понимать сложившуюся картину территориального распределения населения.

Информачионная база. Информационной базой служили материалы Федеральной службы государственной статистики (Росстат) и территориальных органов федеральной службы государственной статистики Белгородской, Воронежской, Курской, Липецкой, Тамбовской областей.

Meтоды. Решение основных задач работы достигнуто применением методов пространственновременного и системного анализов, статистических, моделирования, геоинформационного картографирования (ArcGIS), позволившего наглядно представить временной срез процессов и явлений, отобразить притягательную силу областных метрополий в размещении населения.

\section{РЕЗУЛЬТАТЫ И ОБСУЖДЕНИЕ}

Выявление наиболее значимых результатов трансформации системы расселения, определение тенденций развития метрополисов достигнуто использованием принципа полимасштабности, «сочетания узкого обзора и детализации с широтой и генерализацией» [17]. Для решения задачи использован принцип масштаб-ранга двух уровней: 1) мезоуровень - изучение размещения населения Центрально-Черноземного района; 2) региональный Белгородской области.
1. Метрополизация "региональных столиц" Центрально-Черноземного района в процессах урбанизации. Развитие в Центрально-Черноземном районе (ЦЧР) региональных метрополисов, поляризация расселения в градиенте «центр - периферия», рост количества пустеющих сел протекали в течение длительного времени, но с явным ускорением в XXI веке. Трансформация расселения, обусловленная процессами урбанизации, отличалась пространственными особенностями: до 70-х годов XX столетия городское население составляло абсолютное меньшинство населения областей - от $33 \%$ в Курской до $46 \%$ Воронежской. Перелом в динамике урбанизации, «городская революция» или «урбанистическая революция», порожден индустриализацией областей, вызвавшей взрывообразный рост численности городского населения за счет миграций сельских жителей в города. Развитие городов в ЦЧР происходило в условиях заметно меняющейся демографической ситуации, что повлекло ряд последствий в социально-экономическом развитии областей.

Урбанизационный переход - превышение численности городского населения над числом сельских жителей - свидетельство вступления общества в фазу «зрелого» эволюционного развития был преодолен к концу 70-х годов (1979 г.) в Воронежской, Белгородской, Липецкой, а позднее - Курской и Тамбовской областях. А.Н. Слука [15] отмечает, что урбанизацию, подобно жизненному циклу любого живого организма, можно рассматривать в виде нескольких сменяющихся качественных фаз, каждая из которых имеет свой набор характерных черт и свойств. Смена стадий урбанизации ЦЧР соответствовала трансформации не только направлений расселенческих процессов, но и общественной эволюции. Превышение численности городского населения в $50 \%$ означало переход от преимущественно аграрного типа социальных отношений к индустриально-городскому.

Высокие темпы роста численности городских жителей в районе сохранялись до конца советского периода и протекали в условиях интенсивной концентрации населения в областных центрахметрополисах (в Белгородской области в двух городах-метрополисах - Белгороде и Старом Осколе), формирующихся городских агломерациях. Крайними (полярными), высокими и низкими показателями метрополизации регулярно выделялись Липецкая и Тамбовская области: в 1989 году в городе Липецк было сконцентрировано $37 \%$ от все- 
Динамика численности городского населения, метрополисов областей Центрально-Черноземного района (1989-2019), \%

[Table. The dynamics of the urban population, metropolises of the regions of the Central Chernozem Region (1989-2019), \%]

\begin{tabular}{|c|c|c|c|c|c|}
\hline \multirow{3}{*}{$\begin{array}{c}\text { Численность } \\
\text { населения,\% } \\
\text { [Population] }\end{array}$} & $\begin{array}{l}\text { Белгород- } \\
\text { ская обл. } \\
\text { [Belgorod } \\
\text { region] }\end{array}$ & $\begin{array}{l}\text { Воронеж- } \\
\text { ская обл. } \\
\text { [Voronezh } \\
\text { region] }\end{array}$ & $\begin{array}{c}\text { Курская } \\
\text { область } \\
\text { [Kursk } \\
\text { region] }\end{array}$ & $\begin{array}{c}\text { Липецкая } \\
\text { область } \\
\text { [Lipetsk } \\
\text { region] }\end{array}$ & $\begin{array}{c}\text { Тамбовская } \\
\text { область } \\
\text { [Tambov } \\
\text { region] }\end{array}$ \\
\hline & \multicolumn{5}{|c|}{ Метрополисы [Metropolises] } \\
\hline & $\begin{array}{c}\text { Белгород, } \\
\text { Старый } \\
\text { Оскол } \\
\text { [Belgorod, } \\
\text { Stary } \\
\text { Oskol] }\end{array}$ & $\begin{array}{c}\text { Воронеж } \\
\text { [Voronezh] }\end{array}$ & $\begin{array}{l}\text { Курск } \\
\text { [Kursk] }\end{array}$ & $\begin{array}{c}\text { Липецк } \\
\text { [Lipetsk] }\end{array}$ & $\begin{array}{c}\text { Тамбов } \\
\text { [Tambov] }\end{array}$ \\
\hline \multicolumn{6}{|c|}{1989 Г } \\
\hline Городское & 63 & 61 & 58 & 62 & 56 \\
\hline $\begin{array}{l}\text { Метрополис(ы) в составе } \\
\text { всего населения }\end{array}$ & 35 & 36 & 32 & 37 & 23 \\
\hline $\begin{array}{l}\text { Метрополис(ы) в составе } \\
\text { городского населения }\end{array}$ & 54 & 57 & 55 & 59 & 41 \\
\hline \multicolumn{6}{|c|}{2002 г. } \\
\hline Городское & 65 & 62 & 61 & 64 & 57 \\
\hline $\begin{array}{l}\text { Метрополис(ы) в составе } \\
\text { всего населения }\end{array}$ & 36 & 36 & 33 & 42 & 25 \\
\hline $\begin{array}{l}\text { Метрополис(ы) в составе } \\
\text { городского населения }\end{array}$ & 57 & 58 & 55 & 65 & 44 \\
\hline \multicolumn{6}{|c|}{2010 г. } \\
\hline Городское & 65 & 64 & 65 & 63 & 58 \\
\hline $\begin{array}{l}\text { Метрополис(ы) в составе } \\
\text { всего населения }\end{array}$ & 38 & 38 & 37 & 44 & 26 \\
\hline $\begin{array}{l}\text { Метрополис(ы) в составе } \\
\text { городского населения }\end{array}$ & 58 & 60 & 57 & 69 & 45 \\
\hline \multicolumn{6}{|c|}{2019 г. } \\
\hline Городское & 67 & 68 & 68 & 60 & 61 \\
\hline $\begin{array}{l}\text { Метрополис(ы) в составе } \\
\text { всего населения }\end{array}$ & 40 & 45 & 41 & 49 & 28 \\
\hline $\begin{array}{l}\text { Метрополис(ы) в составе } \\
\text { городского населения }\end{array}$ & 59 & 67 & 60 & 82 & 46 \\
\hline
\end{tabular}

Составлено и рассчитано по [14, 18] [Compiled and calculated by $[14,18]]$.

го населения области и $59 \%$ от населения городов, в то время как в городе Тамбов $23 \%$ и $41 \%$ соответственно (таблица).

Отличительной особенностью метрополизации в Белгородской и Липецкой областях было позднее становление метрополисов - после обретения Белгородом и Липецком «столичных функций» (1954 г.). Интенсивное освоение на территории Белгородской области Курской магнитной аномалии, строительство уникального для того вре- мени бездоменного электрометаллургического комбината привели к формированию еще одного метрополиса - города Старый Оскол, в результате чего сформировалась полицентричная (двухполюсная) метрополизация.

Завершение в постсоветские годы экстенсивного развития урбанизации, ее вступление на качественно иной уровень замедлили темпы демографического роста метрополисов. В настоящее время в метрополисах сосредоточено от $40 \%$ до 
$49 \%$ всего населения и от $59 \%$ до $82 \%$ (Липецк) городского населения. В общем тренде развития урбанизации исключение составляет Тамбовская область, в которой самые низкие показатели доли метрополитенского населения в составе как всего населения, так и городского населения (таблица).

Демографический рост метрополисов, концентрация административно-управленческих функций (весомость экономического потенциала), придают «столицам» дополнительные возможности в конкурентной борьбе за инвестиции и приток населения. Однако, у метрополизации есть и отрицательные следствия процессов «сжатия»: перетягивание населения, производительных сил из малых и средних городов, сельских населенных пунктов в метрополисы приводит к пространственной поляризации экистического и демографического развития центра и периферии (мы не затрагиваем вопросы социально-экономического развития, роста уровня проблемности городского развития: усложнение транспортных проблем; удорожание инженерного оборудования; загрязнение воздушного бассейна; шум; удаленность населения от природы).

Рост численности населения метрополисов сопровождается сокращением численности жителей остальных городов (18\% в Липецкой области, 2019 г.), потенциальным снижением профессионального качества населения из-за оттока инновационно-активного населения. Размещение населения не статично, а подвержено изменениям в связи с экономическими, социальными, политическими и демографическими факторами развития общества, приводящие к миграции населения. Безусловно, что определенное влияние на миграцию жителей из села в город имеют процессы глобализации. Данные Интернет, позволяют осознать несоответствие качества жизни на селе или малом городе современным стандартам. Современные тренды мировой урбанизации хорошо известны: нарастание численности городского населения, развитие процессов субурбанизации и контрурбанизации, концентрация жителей в крупных и сверхкрупных городских образованиях [1].

Не вызывает сомнения утверждение, что концентрации населения в региональных метрополисах избежать на удастся. Но следует отметить, что демографический потенциал уже не может являться ведущим индикатором лидерства и могущества города, как это было на промышленной стадии общественного развития, когда необходима концентрация средств производства и рабочей силы.
В условиях формирования постиндустриального общества вектор определения успешности и значимости города смещается в сферу социально-экономической деятельности. Тем не менее, необходимо определить ближайшее будущее расселения населения ЦЧР. Вступит ли регион в фазу контрурбанизации или продолжится метрополизация областей? Окажет ли радикальное влияние пандемия коронавируса COWID-19 на систему расселения, останутся метрополисы столь же привлекательными для жизни горожан или предпочтительнее станут малые города и сельские населенные пункты?

Полагаем, что крупные города, областные метрополисы останутся притягательными для населения и бизнеса, но не исключаем изменений предпочтений частью населения форм расселения и удаленной занятости. Такова наша гипотеза. Основными «донорами» метрополисов были и останутся жители малых городов и сельских населенных пунктов, поскольку сохранится суммарное наложение факторов: «агломерационный эффект» областных метрополисов, достижения научно-технического прогресса в сельском хозяйстве и последующие сокращения числа занятых, бедная социальная среда за пределами метрополисных ареалов и ряд других.

Проверить верность выдвинутой гипотезы целесообразно на материалах конкретной области ЦЧР - Белгородской (региональный масштаб-ранг, о котором писали выше) с распространением репрезентативности полученных результатов на весь ЦЧР.

2. Белгородская область. Потенциал поля расселения. Изучение размещения населения, его территориальные изменения для эффективного использования обширного массива данных осуществлено методами моделирования и последующего формирования тематических картограмм по Белгородской области.

Определение границ расположения, внутренних зон влияния муниципальных образований решено с использованием модели «потенциала поля расселения», называемой автором концепции (Ч. Стюартом) «демографическим потенциалом», как выражение людской мощи, численности населения той или иной страны, района, города (по [9]) (в отечественной географии термин «демографический потенциал» заменен на «потенциал поля расселения», точнее передающий сущность явления, т.к. речь идет о характеристике поля, создаваемого расселением). Картографирование и анализ потенциала поля расселения позволили определять 


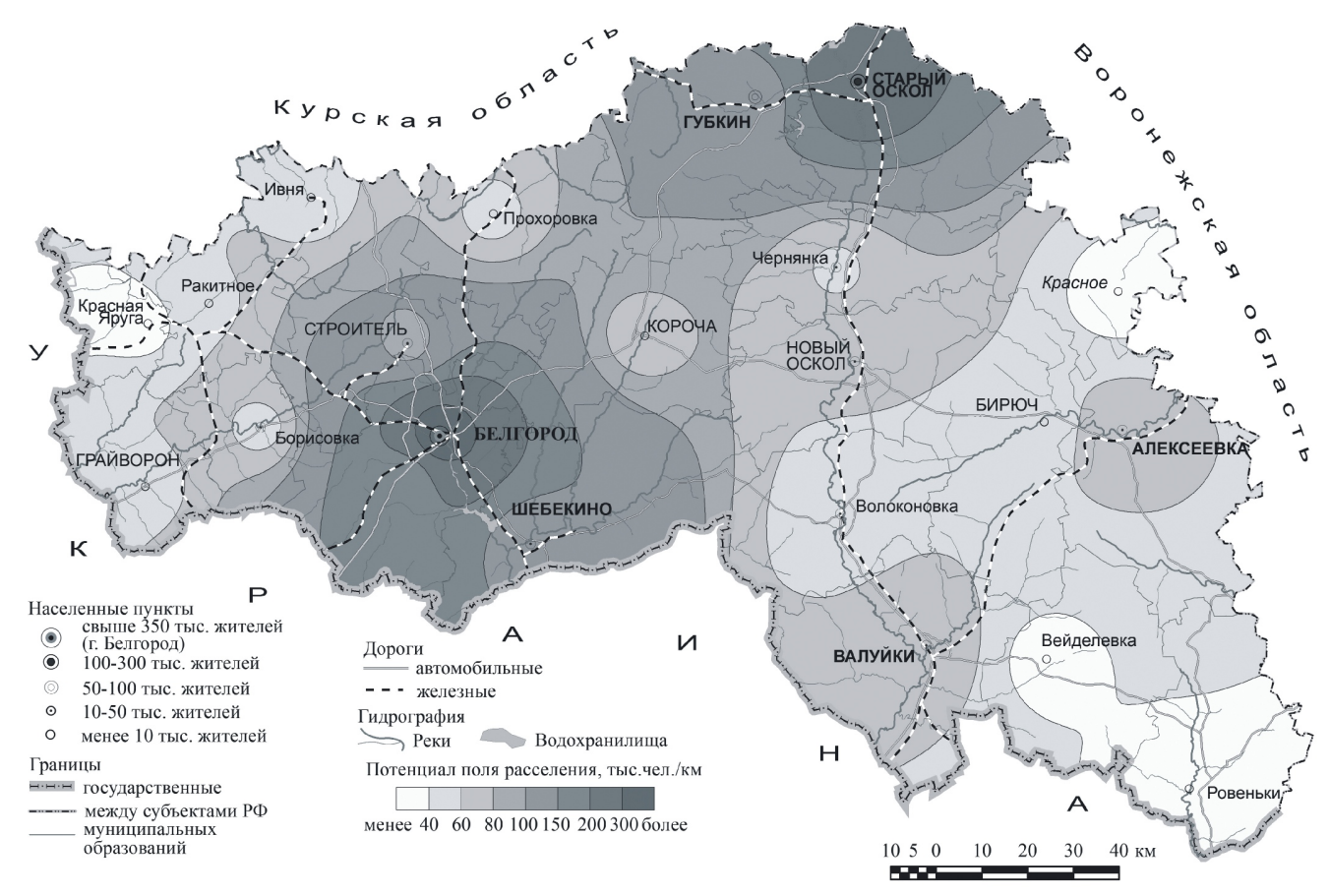

Puc. 1. Потенциал поля расселения Белгородской области. 2019 г. (рассчитано по [13])

[Fig. 1. Potential of the settlement field of the Belgorod region. 2019 (calculated by [13])]

ядра расселения, оценивать их распространение и влияние в пространстве.

Потенциал поля расселения в пределах рассматриваемой территории для каждого населенного пункта есть сумма отношений людности данного и прочих пунктов к расстоянию от данного пункта до всех прочих [9]. На основе данных о численности населения на конкретную дату и расстояний между муниципальными образованиями определен потенциал поля расселения по формуле [16]:

$$
V_{i}=P_{i}+\sum_{1}^{n} \frac{P_{j}}{2 D_{i j}},
$$

где $P_{i}$ - численность населения в пункте, для которого определяется потенциал; $P_{j}$ - численность населения в других пунктах; $D_{i j}$ - расстояние от точки $i$ до точки $j$ (км). Цифра 2 вводится потому, что связи населения по труду, обслуживанию, потреблению осуществляются не только в одном, но и в обратных направлениях.

Рассчитанные значения потенциала поля расселения по муниципальным образованиям были занесены в атрибутивную таблицу районных центров области. Анализ тренда их изменения в пределах области с использованием инструментов Geostatistical Analyst программы ArcGIS показал полинимиальное изменение второй степени (значение использовано при определении параметра степени интерполяции данных). Методом обратно взвешенных расстояний интерполирована поверхность, при этом выбрана сглаженная окрестность (коэффициент сглаживания 0,2), значения ошибки прогнозирования минимальны (средняя ошибка равна 9,2), в полученной модели поля расселения разработана легенда и сформированы картограммы. С целью выявления тенденций изменений потенциала поля расселения области, картограммы рассчитаны и изготовлены на две даты: 2019 год и 2025 год (среднесрочный прогноз) (рис. 1, 2).

Картограмма позволяет видеть значительную концентрацию населения вокруг двух метрополисов Белгородской области - Белгорода и Старого Оскола, одновременно подчеркивая полицентричную метрополизацию области и низкий уровень потенциала поля расселения на периферии области с небольшими очагами влияния городов Алексеевка и Валуйки.

Закономерное демографическое «сжатие» пространства территории, рост «людской мощи» полицентричных метрополисов области - Белгорода и Старого Оскола (включая город Губкин в составе Старооскольско-Губкинской агломерации), 


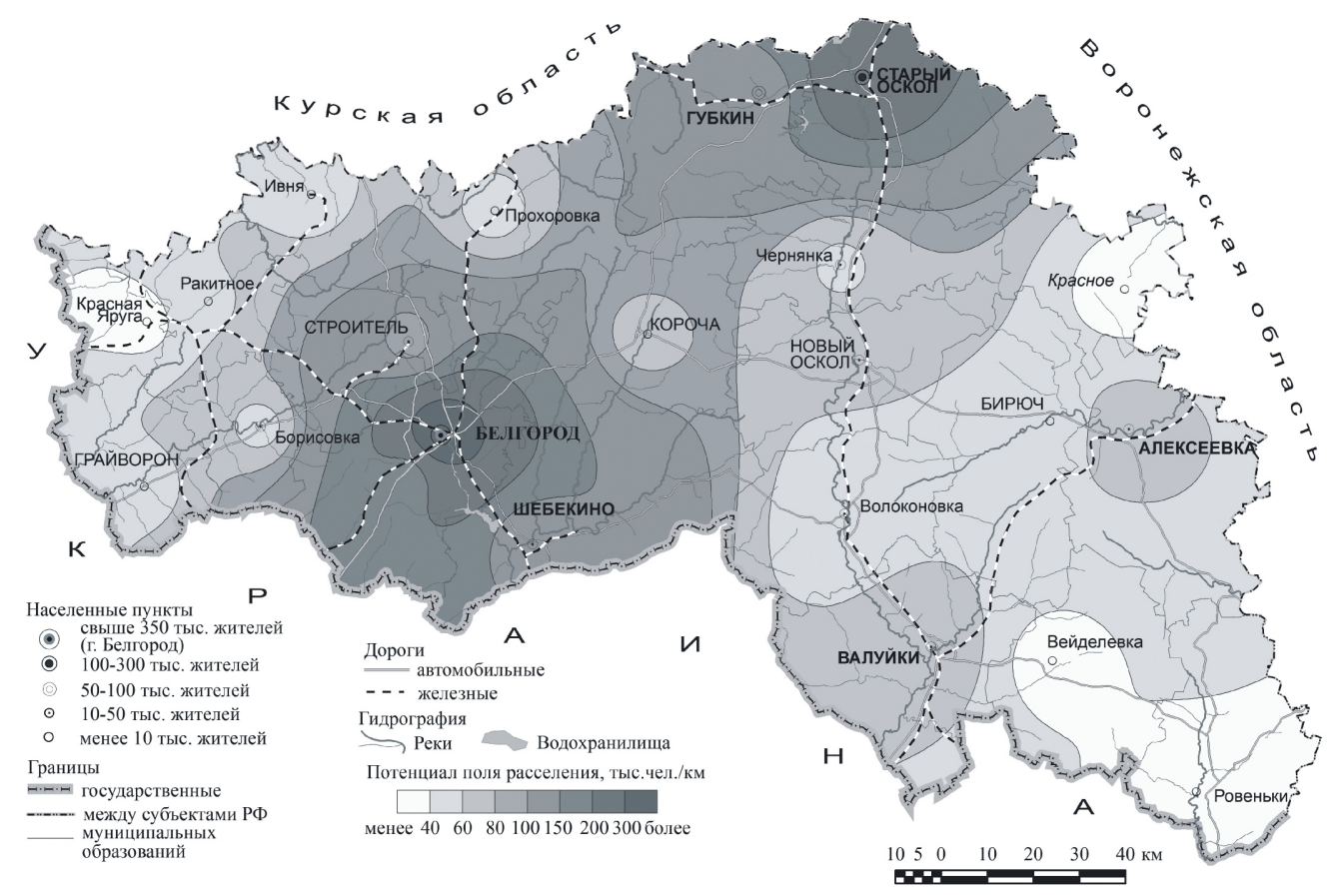

Рuc. 2. Потенциал поля расселения, 2025 г (рассчитано по [13])

[Fig. 2. Potential of the settlement field, 2025 (calculated by [13])]

формирование урбанизированного района между двумя метрополисами и их ареалами, социальное (демографическое) опустынивание периферии области (на востоке и юго-востоке), подтверждено геоинформационным картографированием потенциала поля расселения на прогнозный 2025 год (рис. 2).

Таким образом, в среднесрочной перспективе, зона влияния метрополисов расширится, «крупнейшие города расплываются на сотни верст, как бы навстречу последним «беженцам» с депопулирующей депрессивной периферии» [17].

Возможно, картина расселения области (и не только Белгородской) будет скорректирована (при однозначном доминировании крупных городов и агломераций): мир не останется прежним после окончания пандемии коронавируса 2020 г. Шеринговая экономика (экономика коллективного пользования), которой прочили большое будущее еще несколько месяцев назад, видимо, изменит поступательное развитие и общество вернется к росту индивидуального потребления в расселении: возникновению новых, расширению старых коттеджных поселков не только в первой, второй пригородных зонах региональных метрополисов, но и третьей, четвертой и т.д. Внесет свои коррективы в расселение и изменение форм занятости населе- ния - фрилансерство, удаленная, дистанционная работа. О справедливости нашего предположения свидетельствуют и первые ростки контрурбанизации в зоне влияния метрополисов, отчетливо проявляющиеся на картограммах «Потенциала поля расселения» в форме урбанизированного района.

\section{ВЫВОДЫ}

Процессы урбанизации Центрально-Черноземного района до конца 70-х годов ХХ столетия носили ярко выраженный экстенсивный характер и были вызваны индустриализацией областей. Урбанизационный переход наступил поздно, урбанизированность областей и в XX, и XXI веке была и осталась ниже среднероссийской.

Формирование региональных метрополисов обусловлено процессами урбанизации, но межобластные результаты метрополизации значительны: безоговорочный лидер - Липецк с числом городских жителей $82 \%$, аутсайдер - Тамбов - $46 \%$ городских жителей области, в Белгородской области сформирована полицентричная метрополизация с Белгородом и Старым Осколом.

Развитие региональных метрополисов сопровождалось изменениями соотношений городского и сельского населения, поздним урбанистическим переходом, демографическим опустынивани- 
ем периферийных территорий областей, формируя экистическую неустойчивость.

Притягательная сила для населения и бизнеса областных метрополисов, тенденции их развития, закономерности развития процессов урбанизации свидетельствуют о сохранении доминантной роли региональных метрополисов в системе расселения. Метрополисы останутся реципиентами жителей сел и малых городов периферийных муниципальных образований.

При использовании принципа «масштаб-ранга» методами моделирования и картографирования, анализе потенциала поля расселения Белгородской области на разновременных картограммах были установлены закономерные процессы метрополизации, определены ядра расселения, рост «людской мощи» метрополисов, демографическое «сжатие» пространства и опустынивание периферии.

Как нам представляется роль метрополисов будет сохранена, но пандемия коронавируса 2020 года внесет коррективы в архитектуру расселения: увеличит значимость загородного жилья, ускорит ростки контрурбанизации в зоне влияния метрополисов, небольших городов и сел.

\section{СПИСОК ЛИТЕРАТУРЫ}

1. Алешковский И.А., Болатов М.О., Слука Н. А. Горизонты городского роста в условиях глобализации // Век глобализации, 2017, № 1 Доступно: http:// www.intelros.ru/readroom/vek-globalizacii/ek1-2017/ 32470-gorizonty-gorodskogo-rosta-v-usloviyahglobalizacii.html. Дата обращения 12.03.2020.

2. Бюркнер Х.П. Устойчивость как приоритет // Urban Agenda, 2019, c. 56-57.

3. Вендина О. И., Зотова М. В., Колосов В. А. Международный семинар: «Метрополизация и городские сети» // Известия РАН. Серия географическая, 2010, № 2, c. 130-131.

4. Гонтарь Н. В. Метрополизация как территориальный феномен и фактор капитализации территории // Региональная экономика: теория и практика, 2015, № 10(385), c. 27-35.

5. Дружинин А.Г. Метрополизация как доминантная тенденция территориальной организации общества в постсоветский период: универсальные проявления и южно-российская специфика // Географический вестник, 2009, № 3 (11), с. 54-61.

6. Дружинин А. Г. Метрополизация и региональные метрополии: универсальное и специфическое в южнороссийском контексте // Научная жизнь Кавказа, 2010, № 3, с. 57-62.

7. Зубаревич Н.В. Воздействие глобализации на развитие регионов России: результаты и перспективы //
Крупные города и вызовы глобализачии, 2003, с. 37-53.

8. Колосов В. А., Вендина О.И., Эккерт Д. Региональные центры в условиях глобализации: проблемы сравнительных исследований // Крупные города и вызовы глобализаиии, 2003, с. 5-15.

9. Ковалев С. А., Ковальская Н. Я. География населения СССР: Учебник. Москва, Изд-во МГУ, 1980. $285 \mathrm{c}$.

10. Крупко А. Э. Моделирование и прогнозирование устойчивого развития муниципальных образований ЦЧР // Воронеж: ВГПУ, 2014. 176 с.

11. Крупко А.Э., Михно В.Б. Факторы, проблемы и основные направления устойчивого развития Центрального Черноземного района // Вестник Воронежского государственного университета. Серия География. Геоэкология, 2019, № 1, с. 55-73.

12. Маршан П., Самсон И. Метрополисы и экономическое развитие России // Вопросы экономики, 2004, № 1, c. 4-18.

13. Основные показатели соииально-экономического положения мунииипальных районов и городских округов Белгородской области (2014-2018 гг.). Стат. сб. Белгород, Белгородстат, 2019. 280 с.

14. Регионы России. Социально-экономические показатели. 2019. Стат. сб. Москва, Росстат, 2019. 1402 с.

15. Слука Н. А. Градоиентрическая модель мирового хозяйства. Москва, Пресс-Соло, 2005. 128 с.

16. Тикунов В.С. Моделирование в картографии. Москва, Изд-во МГУ, 1997. 403 с.

17. Трейвиш А. И. Географическая полимасштабность в развитии России. Доступно: https://geo.1sept.ru/ article.php?ID=200601102 (Дата обращения 5.04.2020)

18. Федеральная служба государственной статистики. Доступно: http://kurskstat.gks.ru/wps/wcm/connect /rosstat_ts/kurskstat/resources/ee617b804e86dcf6bf81ffb8 fc91c3ba/\%D1\%82\%D0\%BE\%D0\%BC+1.pdf. (Дата обращения 5.04.2020)

19. Флорида Р. Новый кризис городов: джентрификаиия, дорогая недвижимость, растущее неравенство и что нам с этим делать. Москва, Изд. группа «Точка», 2018. 368 с.

20. Чугунова Н.В., Лихневская Н.В. Пространственная дифференциация уровня жизни населения как отражение диспропорций социально-экономического развития (на примере Белгородской области) // Известия РАН. Серия географическая, 2019, № 3, с. 28-40.

21. Чугунова Н.В., Полякова Т.А., Деловая Е.В., Игнатенко С. А. Особенности современного социальноэкономического и экистического развития пригородной зоны агломерации // Проблемы региональной экологии, 2012, № 2, c. 35-43.

22. Чугунова Н.В., Полякова Т. А., Романов И.В. Результаты и тренды развития региональной системы расселения в эпоху неолиберальной урбанизации (на материалах Белгородской области) // Географический вестник, 2019, № 2(49), с. 34-45. 
23. Friedmann J. Regional Development Policy: A Case Study of Venezuela. MIT Press: 1966. 279 p.
Конфликт интересов: Авторы декларируют отсутствие явных и потенциальных конфликтов интересов, связанных с публикацией настоящей статьи.

\title{
Metropolization of Regional Capitals of the Central Chernozem Region in the Transformation of Population Distribution
}

\author{
N. V. Chugunova ${ }^{\circledR}$, T. A. Polyakova, D. N. Morkovskaya \\ Belgorod National Research University, Russian Federation \\ (85, Pobeda St., Belgorod, 308015)
}

\begin{abstract}
Purpose: determination of the role of the metropolises of the regional capitals of the Central Chernozem Region in the transformation of population settlement. The information base was the materials of the Federal State Statistics Service (Rosstat) and the territorial bodies of the federal state statistics service of the Belgorod, Voronezh, Kursk, Lipetsk, Tambov regions. Methods. The solution of the main tasks of the work was achieved by using methods of spatiotemporal and system analyses, statistical, modeling, geoinformation mapping (ArcGIS), which made it possible to clearly represent the timeframe of processes and occurrence, to display the attractive force of regional metropolises in the distribution of population. Results. Natural changes in the development of settlement caused by the processes of urbanization, metropolization of the regions of the Central Chernozem Region have been revealed. The peculiarities of the formation of regional metropolises have been established; the scope and trends of population placement at different territorial levels have been identified. A model study of population placement was tested, the potential of the settlement field of the Belgorod region was mapped. Using the rang and size principle in the study will allow management institutions of different hierarchical levels to see and solve acute problems of resettlement.
\end{abstract}

Key words: settlement, metropolises, metropolization, potential of the settlement field, Central Black Earth, Belgorod region.

Funding: The article was prepared as part of the Scientific Project of RFBR No. 20-05-00074.

For citation: Chugunova N. V., Polyakova T. A., Morkovskaya D. N. Metropolization of regional capitals of the Central Chernozem Region in the transformation of population distribution. Vestnik Voronezskogo gosudarstvennogo universiteta. Seria Geografia. Geoekologia, 2020, No. 4, pp. 3-13. (In Russ.) DOI: https://doi.org/10.17308/geo.2020.4/3060

\section{REFERENCES}

1. Aleshkovskij I. A., Bolatov M. O., Sluka N. A. Gorizonty gorodskogo rosta $\mathrm{v}$ usloviyah globalizacii [Urban growth horizons in the context of globalization]. Vek globalizacii, 2017, no. 1. Available at: http://www.intelros.ru/ readroom/vek-globalizacii/ek1-2017/32470-gorizontygorodskogo-rosta-v-usloviyah-globalizacii.html (accessed 12.03.2020) (In Russ.)

2. Byurkner H.P. Ustojchivost' kak prioritet [Sustainability as a priority]. Urban Agenda, 2019, pp. 56-57. (In Russ.)
3. Vendina O. I., Zotova M. V., Kolosov V. A. Mezhdunarodnyj seminar: "Metropolizaciya i gorodskie seti" [International seminar "Metropolization and state nets"]. Izvestiya RAN. Seriya geograficheskaya, 2010, no. 2, pp. 130131. (In Russ.)

4. Gontar' N.V. Metropolizaciya kak territorial'nyj fenomen i faktor kapitalizacii territorii [Metropolization as a factor and mechanism of territorial capitalization]. Regional'naya ekonomika: teoriya i praktika, 2015, no. 10 (385), pp. 27-35. (In Russ.)

(C) Chugunova N. V., Polyakova T. A., Morkovskaya D. N., 2020

凶 Nadezhda V. Chugunova, e-mail: chugunova@bsu.edu.ru

The content is available under Creative Commons Attribution 4.0 License. 
5. Druzhinin A. G. Metropolizaciya kak dominantnaya tendenciya territorial'noj organizacii obshchestva v postsovetskij period: universal'nye proyavleniya i yuzhno-rossijskaya specifika [Metropolisation as a dominant tendency of spatial organization of society in the post-soviet period: universal displays and south-Russian specificity]. Geograficheskij vestnik, 2009, no. 3 (11), pp. 54-61. (In Russ.)

6. Druzhinin A.G. Metropolizaciya i regional'nye metropolii: universal'noe i specificheskoe v yuzhnorossijskom kontekste [Metropolisation and the regional metropolises: universal and particular in the south Russia context]. Nauchnaya zhizn' Kavkaza, 2010, no. 3, pp. 57-62. (In Russ.)

7. Zubarevich N. V. Vozdejstvie globalizacii na razvitie regionov Rossii: rezul'taty i perspektivy [Impact of globalization on the development of Russian regions: results and prospects]. Krupnye goroda $i$ vyzovy globalizacii, 2003, pp. 37-53. (In Russ.)

8. Kolosov V. A., Vendina O. I., Ekkert D. Regional'nye centry v usloviyah globalizacii: problemy sravnitel'nyh issledovanij [Regional centers in the context of globalization: problems of comparative research]. Krupnye goroda $i$ vyzovy globalizacii, 2003, pp. 5-15. (In Russ.)

9. Kovalev S. A., Koval'skaya N. YA. Geografiya naseleniya SSSR [Geography of the population of the USSR]. Moscow, Izd-vo MGU Publ., 1980. 285 p. (In Russ.)

10. Krupko A. E. Modelirovanie i prognozirovanie ustojchivogo razvitiya municipal'nyh obrazovanij CCHR [Modeling and forecasting sustainable development of municipalities in the Central Chernozem Region]. Voronezh, VGPU, 2014, 176 p. (In Russ.)

11. Krupko A.E., Mihno V. B. Faktory, problemy i osnovnye napravleniya ustojchivogo razvitiya Central'nogo CHernozemnogo rajona [The factors, problems and main directions of sustainable development of the Central Black Soil Region]. Vestnik Voronezskogo gosudarstvennogo universiteta. Seria Geografia. Geoekologia, 2019, no. 1, pp. 55-73. (In Russ.)

12. Marshan P., Samson I. Metropolisy i ekonomicheskoe razvitie Rossii [Metropolises and economic development of Russia]. Voprosy ekonomiki, 2004, no. 1, pp. 4-18. (In Russ.)

13. Osnovnye pokazateli social'no-ekonomicheskogo polozheniya municipal'nyh rajonov $i$ gorodskih okrugov Belgorodskoj oblasti (2014-2018 gg.) [The main indicators of the socio-economic situation of municipal districts and urban districts of the Belgorod region (2014-2018)]. Stat. sb. Belgorod: Belgorodstat, 2019. 280 p. (In Russ.)
14. Regiony Rossii. Social'no-ekonomicheskie pokazateli. 2019 [Regions of Russia. Socio-economic indicators. 2019]. Moscow, Rosstat Publ., 2019. 1402 p. (In Russ.)

15. Sluka N. A. Gradocentricheskaya model' mirovogo hozyajstva [City-centric model of the world economy]. Moscow, Press-Solo Publ., 2005, 128 p. (In Russ.)

16. Tikunov V.S. Modelirovanie v kartografii [Modeling in cartography]. Moscow, Izd-vo MGU Publ., 1997. 403 p. (In Russ.)

17. Trejvish A. I. Geograficheskaya polimasshtabnost' v razvitii Rossii [Geographic poly-scale in the development of Russia]. Available at: https: geo.1sept.ru/ article.php?ID=200601102. (accessed 5.04.2020) (In Russ.)

18. Federal'naya sluzhba gosudarstvennoj statistiki [Federal State Statistics Service]. Available at: http: kurskstat.gks.ru/wps/wcm/connect/rosstat_ts/kurskstat/resources/ee6 $17 \mathrm{~b} 804 \mathrm{e} 86 \mathrm{dcf} 6 \mathrm{bf} 81 \mathrm{ffb} 8 \mathrm{fc} 91 \mathrm{c} 3 \mathrm{ba} /$ $\% \mathrm{D} 1 \% 82 \% \mathrm{D} 0 \% \mathrm{BE} \% \mathrm{D} 0 \% \mathrm{BC}+1 . \mathrm{pdf}$. (accessed 5.04.2020) (In Russ.)

19. Florida R. Novyj krizis gorodov: dzhentrifikaciya, dorogaya nedvizhimost', rastushchee neravenstvo i chto nam s etim delat' [New urban crisis: gentrification, expensive real estate, growing inequality and what we do about it.]. Moscow, Publ. "Tochka", 2018. 368 p. (In Russ.)

20. CHugunova N. V., Lihnevskaya N. V. Prostranstvennaya differenciaciya urovnya zhizni naseleniya kak otrazhenie disproporcij social'no-ekonomicheskogo razvitiya (na primere Belgorodskoj oblasti) [Spatial differentiation of Living Standards as a mirror of disproportions in Socioeconomic development: a Case Study of Belgorod Region]. Izvestiya RAN. Seriya geograficheskaya, 2019, no. 3, pp. 28-40. (In Russ.)

21. CHugunova N. V., Polyakova T. A., Delovaya E. V., Ignatenko S. A. Osobennosti sovremennogo social'no-ekonomicheskogo i ekisticheskogo razvitiya prigorodnoj zony aglomeracii [Features the socio-economic and ekistics developments of a residential suburb of agglomeration]. Problemy regional'noj ekologii, 2012, no. 2, pp. 35-43. (In Russ.)

22. CHugunova N. V., Polyakova T. A., Romanov I. V. Rezul'taty i trendy razvitiya regional'noj sistemy rasseleniya v epohu neoliberal'noj urbanizacii (na materialah Belgorodskoj oblasti) [Results and trends of the regional settlement system development in the era of neoliberal urbanization (a case study of the Belgorod region]. Geograficheskij vestnik, 2019, no. 2 (49), pp. 34-45. (In Russ.)

23. Friedmann J. Regional Development Policy: A Case Study of Venezuela. MIT Press: 1966. 279 p.

Conflict of interests: The authors declare no information of obvious and potential conflicts of interest related to the publication of this article.

Received: 24.08.2020

Accepted: 20.11.2020 
Чугунова Надежда Васильевна

кандидат географических наук, доцент кафедры природопользования и земельного кадастра Института наук о Земле Белгородского государственного национального исследовательского университета, г. Белгород, Российская Федерация,

ORCID: https://orcid.org/0000-0003-3180-7766, e-mail: chugunova@bsu.edu.ru

Полякова Татьяна Анатольевна

кандидат географических наук, доцент кафедры природопользования и земельного кадастра Института наук о Земле Белгородского государственного национального исследовательского университета, г. Белгород, Российская Федерация,

ORCID: https://orcid.org/0000-0002-9100-1599, e-mail: polyakova_t@bsu.edu.ru

Морковская Дарья Николаевна

студент Белгородского государственного национального исследовательского университета, г. Белгород, Российская Федерация
Nadezhda V. Chugunova

Cand. Sci. (Geogr.), Associate Professor of the Department of nature management and land cadastre of the Institute of Earth Sciences of the Belgorod National Research University, Belgorod, Russian Federation, ORCID:

https://orcid.org/0000-0003-3180-7766, e-mail: chugunova@bsu.edu.ru

Tatyana A. Polyakova

Cand. Sci. (Geogr.), Associate Professor of the Department of nature management and land cadastre of the Institute of Earth Sciences of the Belgorod National Research University, Belgorod, Russian Federation, ORCID:

https://orcid.org/0000-0002-9100-1599, e-mail: polyakova $\mathrm{t} @$ bsu.edu.ru

Daria N. Morkovskaya

Student of the Belgorod National Research University, Belgorod, Russian Federation 